\title{
Towards a more democratic Europe: De-constitutionalization and Majority Rule
}

European integration has come to constrain the capacity for democratic political action in EU member states through the judicial constitutionalization of "economic liberties". At the same time, the capacity for effective political action at the European level is narrowly constrained by the multiple-veto character of the Union's "ordinary legislative procedure" - which is considered essential for preserving the legitimacy of European government in the absence of a politically integrated European polity. The article explores conditions under which democratic governing capacity could be legitimately increased on both levels.

\section{The asymmetric impact of excessive constitutionalization}

In the European Union, the Treaties are legally binding for European and national authorities and their legislative, executive, administrative, and judicial actions. In this regard, they perform the functions ascribed to the "basic law" in constitutional democracies; they are even harder to change than most national constitutions; and just like national constitutional courts, the European Court of Justice (ECJ) has the final say in their authoritative interpretation. But the Treaties differ from national constitutions in crucial respects: a "lean" federal constitution must have rules organizing the federal level of government; it must also allocate governing competences to the levels of government; and it will usually stipulate a number of fundamental rights protecting basic human and citizen rights and freedoms against the exercise of governing powers. The European Treaties, however, go far beyond these core functions by regulating in considerable detail a wide range of matters that democratic constitutions would leave to be determined by political legislation. ${ }^{1}$ In comparison to constitutional federal states, therefore,

1 Grimm, D.: 2015: The Democratic Costs of Constitutionalization: The European Case, in: European Law Journal 21/4 (2015), 460-473; ders.: Europe's Legitimacy Problem and the Courts, in: Chalmers, D./Jachtenfuchs, M./Joerges, C. (ed.): The End of the Eurocrats' Dream: Adjusting to European Diver- 
there is considerably more constitutional law in the European Union, and thus a much larger domain for the judicial interpretation, extension and potential enforcement of constitutional constraints on political action.

\section{The problem}

By itself, the greater coverage of the Treaties affects the horizontal and the vertical balance of powers. In the horizontal dimension, it reduces the domain of political legislation and enlarges the space for authoritative judicial interpretation - which becomes the only mode through which changes in primary law can be brought about without a unanimous Treaty amendment. In the vertical dimension, it also constrains member states in areas where, in the absence of federal legislation, policy could have been shaped by national political action. What matters most for member states, however, is the fact that the Treaties have also come to incorporate an economic constitution that places the rules governing economic relations and economic policy beyond political determination.

This idea, which is alien to the constitutions of democratic states, whether federal or unitary, originated in Germany in the 1930s within the "ordoliberal" variant of normative economic theory. Opposed to both laissez-faire liberalism and state interventionism, it advocated a rules-based economic regime in which state intervention would be necessary but essentially limited to ensuring the stability of money and preventing the self-destruction of competitive markets through economic concentration and cartels. After the Second World War, ordoliberal principles had considerable influence on German economic and legal theory, ${ }^{2}$ and also on the monetary and competition policies shaping the German "social market economy." But efforts to have the underlying principles constitutionalized failed in the assemblies drafting the Basic Law and in the Federal Constitutional Court, which, in an early decision ${ }^{3}$, held that democratically accountable governments and parliaments, though bound by the basic human and citizen rights protected by the Constitution, were not constrained by the doctrines of any economic theory in their choice of economic policies and market interventions.

However, what had failed in Germany succeeded in the European Economic Community, whose competition rules were framed under German juristic influence

sity, Cambridge, 2016, 241-265; ders.: Europa ja - aber welches? Zur Verfassung der europäischen Demokratie, München, 2016.

2 Ehmke, H.: Wirtschaft und Verfassung: Die Verfassungsrechtsprechung des Supreme Court zur Wirtschaftsregulierung, Karlsruhe, 1961, 7-55.

3 BVerfGE 4, 7, 20.07.1954. 
and whose early practice was shaped by a German head of the Competition Directory committed to ordoliberalism. ${ }^{4}$ What mattered even more in the long run, however, was the ECJ's interpretation of Treaty provisions regarding the abolition of tariffs and the free movement of goods, services, capital, and workers. They might have been treated as political commitments to a goal that was to be realized through European legislation. Instead, the Court elevated them to the status of "economic liberties" - that is, subjective rights of individuals and corporations that, invested with the properties of "direct effect" and "supremacy," came to have the legal force of fundamental rights that must be respected by all levels of government.

The Treaty of Rome had, of course, not included any of the typical constitutional rights of life, liberty, property, free speech, free press, or free association that are generally protected by national constitutions. Instead, the Court's interpretation of economic liberties transformed issues that in national constitutions would be settled by political legislation into constitutional rights that are constraining political choices at the European and national levels. In hindsight, this interpretation may be construed as a revolutionary act of judicial self-empowerment ${ }^{6}$ that placed the Court's interpretation of economic liberties not only above member states' laws and constitutions, but also beyond the political choice of European legislation. Its doctrinal bases had been developed and disseminated by a transnational network of "Euro-Law" associations " ; politically, the Court's authority was not effectively challenged by the "Masters of the Treaty", ; and it is now generally accepted by national courts as well. ${ }^{9}$

As a practical consequence of the constitutionalization of economic liberties, private litigants are empowered to challenge national law in ordinary courts which are then obliged to submit claims not yet supported by the settled case law

4 From 1958 to 1967, Hans von der Groeben, a high civil servant in Ludwig Erhard's Ministry of Economic Affairs, was the first Director General for Competition in the European Commission. See also Gerber, D. J.: Constitutionalizing the Economy: German Neo-liberalism, Competition Law and the "New" Europe, in: American Journal of Comparative Law, 42/1 1988, 25-84; Wegmann, M.: Der Einfluss des Neoliberalismus auf das Europäische Wettbewerbsrecht 1946-1965: Von den Wirtschaftswissenschaften zur Politik, Baden-Baden, 2008.

5 Van Gend en Loos vs. Netherlands (1963); Costa vs. Enel (1964).

6 Alter, $K . J$.: Establishing the Supremacy of European Law: The Making of an International Rule of Law in Europe, Oxford, 2001; Grimm, D.: Democratic Costs, loc. cit.; ders.: Europe's Legitimacy Problem, loc. cit.

7 Vauchez, A.: "Integration through Law": Contribution to a Socio-History of EU Political Commonsense, in: EUI Working Papers, RSCAS 10 (2008); Alter, K. J.: Jurist Advocacy Movements in Europe: The Role of Euro-Law Associations in European Integration (1953-1975), in: ders. (ed.): The European Court's Political Power: Selected Essays, Oxford, 2009, 63-91

8 Alter, K. J.: Who Are the "Masters of the Treaty"? European Governments and the European Court of Justice. in: ders.: The European Court's Political Power, loc. cit., 109-136.

9 Stone Sweet, A.: The Judicial Construction of Europe, Oxford, 2004; Kelemen, R. D.: Eurolegalism: The Transformation of Law and Regulation in the European Union, Cambridge, MA, 2001. 
to the ECJ for a preliminary opinion. It is this combination of self-interested litigation pushing against the boundaries of the current case law with the Court's methodological commitment to "teleological interpretation" principle, and its own role as a "motor of integration" 11 that has dynamically extended the protection of economic liberties - moving from intervention against protectionist discrimination to the removal of non-discriminatory potential "impediments" to economic choice ${ }^{12}$, from the free movement of goods to all other economic liberties, and from the free movement of workers to mobility rights derived from European citizenship.

In light of the obvious difficulty of harmonization through consensual legislation, judicial legislation promoting "integration through law", 14 was widely considered a welcome "bypass" to avoid potential political blockades. ${ }^{15}$ And indeed, the famous Cassis decision ${ }^{16}$ of 1978 was then used by the Commission to promote political agreement on the Single European Act and the move from unanimity to qualified majority voting, as even governments as yet unconverted to the neoliberal creed ${ }^{17}$ came to prefer the legislative harmonisation of basic standards to the uncertainties of judicially imposed "mutual recognition". 18

Yet, even after the Single European Act had generated an avalanche of European legislation on product standards promoting work safety and environmental and consumer protection, the leadership of judicial "negative integration" and liberalisation was maintained through the progressive widening and deepening of the reach of economic liberties and European competition law. Thus the domain of free service provision was extended to include public-sector banks ${ }^{19}$ and a wide range of functions that had been performed by public infrastructure and public or

10 Itzcovich, G.: The Interpretation of Community Law by the European Court of Justice, in: German Law Journal, 10/5 (2011), 537-560.

11 Horsley, $T$ : Reflections on the Role of the Court of Justice as the "Motor" of European Integration: Legal Limits to Judicial Lawmaking, in: Common Market Law Review, 50/4 (2013), 931-964.

12 Barnard, C.: Restricting Restrictions: Lessons for the EU from the US?, in: Cambridge Law Journal, 68/3 (2009), 575-606.

13 Schmidt, S. K.: Who Cares about Nationality? The Path-dependent Case Law of the ECJ from Goods to Citizens, in: Journal of European Public Policy, 19/1 (2012), 8-24.

14 Cappelletti, M. et al. (ed.): Integration through Law: Europe and the American Federal Experiment, $5^{\text {th }}$ ed., Berlin, 1985 .

15 Genschel, P.: One Trap, Many Exits, but No Free Lunch: How the Joint-Decision Trap Shapes EU Tax Policy, in: Falkner, G. (ed.): The EU's Decision Traps: Comparing Policies, Oxford, 2011, 54-72.

16 Case C-120/79 (1979).

17 Jabko, N.: Playing the Market: A Political Strategy for Uniting Europe, 1985-2005, Ithaca, 2006.

18 Schmidt, S. K.: Mutual Recognition as a New Mode of Governance, in: Journal of European Public Policy 14/5 (2007), 667-681.

19 Seikel, D.: Der Kampf um öffentlich-rechtliche Banken: Wie die Europäische Kommission Liberalisierung durchsetzt, Frankfurt a. M., 2013. 
publicly subsidized social services in most member states. ${ }^{20}$ The right of free establishment was extended by the Centros decision ${ }^{21}$ to prevent the application of national company law to firms established as letter-box companies abroad for the sole purpose of operating domestically ${ }^{22}$; and free capital movement was seen to be violated by national attempts to constrain tax evasion ${ }^{23}$ and strengthen stakeholder representation in shareholder assemblies. ${ }^{24}$ And finally, in a series of (in)famous decisions in 2007 and $2008,{ }^{25}$ the freedom of service provision was also held to override national wage regulations and collective-bargaining and collective-action rights. ${ }^{26}$

In this context, it is worth noting that the Court's enforcement of economic liberties and European competition law is not constrained by the allocation of governing competences between the Union and its member states, or even by Treaty clauses such as Articles 153, 5 or 168, 7 of the Treaty on the Functioning of the European Union (TFEU), which explicitly preclude the exercise of European competences. $^{27}$ This effect appears constitutionally appropriate where basic human rights are at stake. But in light of the fact that in modern capitalism economic interactions have come to pervade all aspects of society, the Court may now intervene in the full range of national governing powers - whenever there are litigants, individuals, or corporations who find it in their interest to push for the greater extension of economic liberties or unfettered competition.

This is not meant to say that such efforts will invariably succeed. The Court may use its version of the proportionality test to tolerate some national constraints on economic liberty. Nevertheless, the balance between economic interests and public purposes is no longer defined by democratically accountable national

20 This is not meant to deny the influence of OECD-wide beliefs supporting the neoliberal transformation of the post-war "mixed economies" since the 1980 s (for a comparative account, see Wollman, H. et al. (ed.): Public and Social Services in Europe: From Public and Municipal to Private Sector Provision, Basingstoke, 2016). But the ECJ's case law facilitated the implementation in member states that were resisting. See also Sauter, W.: Public Services in EU Law, Cambridge, 2014.

21 Case C-212/97 (1999).

22 Lowry, J.: Eliminating Obstacles to Freedom of Establishment: The Competitive Edge of UK Company Law, in: The Cambridge Law Journal 63/2 (2004), 331-345.

23 Genschel, P., loc. cit.

24 Werner, B. : Der Streit um das VW-Gesetz: Wie Europäische Kommission und Europäischer Gerichtshof die Unternehmenskontrolle liberalisieren, Frankfurt a. M, 2013.

25 Viking, C-438/05; Laval, C-341/05; Rueffert, C-346/06; Luxembourg, C-319/06.

26 Rödl, F.: Private Law, Democracy, Codification: A Critique of the European Law Project, in: Joerges, C./Ralli, T. (ed.): European Constitutionalism without Private Law: Private Law without Democracy, ARENA Report 3 (2011).

27 The standard argument is that even in the exercise of their undisputed governing competences member states must of course respect the subjective rights of individuals and corporations that are protected by the Treaties (e.g., Kohl C-158/96, 19-20). 
governments and parliaments, but ultimately by a Court that is committed not only to the priority of European over national competences but also to the promotion of a liberal economic constitution.

In effect, the extension of judicial surveillance over the exercise of national competences has created a highly asymmetric regime for the heterogeneous political economies of EU member states. Given the historical, institutional, and political differences between "liberal" and "coordinated market economies" 28 and between "liberal", "Bismarckian", and "social democratic" welfare states ${ }^{29}$, European states had defined different boundaries between state, market, and civil society. They had adopted different mixes of tax-financed, work-based and commercial social security, and of public, not-for-profit, and private social services; and their industrial relations and wage-setting institutions were corporatist, statist, or decentralized, to mention just some of the differences. In general, therefore, in the non-liberal Scandinavian and Continental "social market economies", capitalism was more "organized" and the provision of goods, services and infrastructure was to a larger part "mixed" between the state or societal organisations and the market than was generally (but not without significant exceptions, like the British National Health Service, NHS) the case in the more "liberal" Anglo-Irish political economies. These differences had three crucial implications.

First, since the non-liberal institutional configurations and policy legacies had been historically shaped by national policy choices reflecting the contingent outcomes of class battles and political compromises, they differed significantly from one country to another. By the same token, further policy changes were likely to have high political salience as well.

Second, to the extent that these non-liberal national solutions (including the NHS) had the effect of limiting the domain of market competition, they were obviously the primary target of the ECJ's protection of economic liberties against "impediments" to their exercise. Equally important, however, were the differences among non-liberal national solutions. Even if these could pass the Court's "proportionality" tests individually, transnational differences would still constitute "non-tariff barriers" to economic mobility - with the consequence that the ECJ's requirement of "mutual recognition" would undermine the economic

28 Hall, P./Soskice, D. (ed.): Varieties of Capitalism: The Institutional Foundations of Comparative Advantage, Oxford, 2001.

29 Esping-Andersen, G.: The Three Worlds of Welfare Capitalism, Cambridge, 1990. 
and political viability of more demanding national solutions ${ }^{30}$. In practical effect, therefore, the impact of the judicially defined and enforced expansion of the domain of Treaty-based economic liberties was necessarily, and almost exclusively, targeted at the institutions and policy legacies of the non-liberal member states of the Community and the Union.

Third, the "legitimate diversity",31 among non-liberal political economies also frustrated the promise of a "social dimension" of European integration that Jacques Delors had associated with the completion of the "Single Market" program in $1992 .^{32}$ Even after the mid-1990s and before Eastern enlargement, when centre-left governments for a while had a majority at the European level, there was no progress in creating non-liberal regimes at the European level, and no agreement on legislative harmonisation that could stop the erosion of non-liberal national systems of social protection, industrial relations, and corporate governance $^{33}$, whereas a series of Treaty amendments that tried to protect national autonomy in such fields as education, healthcare, and industrial relations by explicitly limiting European competences could not, for the reasons mentioned above, stop the progress of judicial liberalisation.

In effect, therefore, the advancement of European economic integration through the judicial extension and enforcement of Treaty-based economic liberties has had an asymmetric negative impact on the institutions and policy legacies of non-liberal political economies - whereas member states with liberal economic institutions and practices have hardly been affected. ${ }^{34}$ This asymmetry cannot be corrected at the European level because the historically shaped configurations of non-liberal member states are "parochial" 35 in the sense that none of them could find acceptance as a template of uniform European solutions. Under these conditions, the legal erosion of national non-liberal systems will have a default out-

30 Schmidt, S. K: Mutual Recognition, loc. cit.; dies.: Law Making in the Shadow of Judicial Politics, in: Dehousse, R. (ed.): The "Community Method": Obstinate or Obsolete? Basingstoke, 2009, 43-59.

31 Scharpf, F. W.: Legitimate Diversity: The New Challenge of European Integration, in: ZSE 1/1 (2003), 32-60.

32 Delors, J.: The Social Dimension, Address by President Delors at the Trades Union Congress, Bournemouth, 08.09.1988.

33 Barnard, C.: EU Employment Law and the European Social Model, in: Legal Studies Research Paper 43 (2014).

34 In this regard, the asymmetric impact of the European regime of economic liberties on "liberal" and "non-liberal" political economies resembles the asymmetric impact of the regime upholding the European Monetary Union on "Northern" and "Southern" political economies (See Scharpf, F. W.: Forced Structural Convergence in the Eurozone: Or a Differentiated European Monetary Community, in: MPIfG Discussion Paper, Cologne, 2016, forthcoming.). In both cases, the asymmetry arises if a uniform European regime is imposed on structurally heterogeneous national polities, economies, and societies.

35 Streeck, W.: German Capitalism: Does It Exist? Can It Survive?, in: New Political Economy, 2/2 (1997), 237-256. 
come that approaches the liberal model, while legislation at the European level will be under constitutional and political constraints favouring the codification of the ECJ's case law and market-making consensual rules. ${ }^{36}$ In other words, the EU cannot become a social-market economy. ${ }^{37}$

In member state politics, however, the progressive expansion of legal constraints on non-liberal institutions and practices has generally had low political salience. One reason is that judicial legislation works through decisions in individual cases whose specific details will often appear unspectacular or even trivial and will catch the attention of political parties, trade unions and the media only under exceptional circumstances - as was partly true in the Laval-Viking series of interventions in collective action or in the Volkswagen case. ${ }^{38}$ And even if governments are aware of the negative policy implications of the decisions, there is no legal remedy against Treaty-based ECJ judgments; political responses that would have to mobilise support for a unanimous Treaty amendment appear quite unpractical; and open defiance through explicit noncompliance ${ }^{39}$ would bring governments in conflict with their own national legal order and their commitment to the rule of law. It is not surprising, therefore, that even governments strongly opposed to a ruling have generally not only accepted the decision of the specific case, but also accommodated their administrative responses and subsequent policy choices. ${ }^{40}$ A similar avoidance of open conflict has characterized responses by the Council and the European Parliament (EP) to Treaty-based ECJ decisions that nullified or modified European legislation.

By and large, therefore, "integration through law" has not only progressed through non-political processes relying on the institutional independence and supranational authority of the $\mathrm{ECJ}^{42}$; it has also generated remarkably little open opposition at the national and European levels; and it has hardly been touched by

36 Schmidt, S. K.: The European Court of Justice and the Policy Process: The Shadow of the Case Law, Oxford, 2017, forthcoming.

37 Scharpf, F. W: The Asymmetry of European Integration or Why the EU Cannot Be a Social Market Economy, in: Socio-Economic Review 8/2 (2010), 211-250.

38 C-112/05 (2007). See also Höpner, M.: Integration durch Usurpation - Thesen zur Radikalisierung der Binnenmarktintegration, in: WSI Mitteilungen, 8 (2009), 407-415; Werner, B., loc. cit.

39 There is, of course, a lot of tacit noncompliance in the EU (Conant 2002) - which, however, will not be able to challenge the legal validity of the Court's rule for law-abiding member states.

40 Blauberger, M.: With Luxembourg in Mind - the Remaking of National Policies in the Face of ECJ Jurisprudence, in: Journal of European Public Policy, 19/1 (2012), 109-126.

41 Martinsen, D. S.: An Ever More Powerful Court? The Political Constraints of Legal Integration in the European Union. Oxford, 2015; Davies, G.: The European Union Legislature as an Agent of the European Court of Justice, in: Journal of Common Market Studies 54/4 (2016), 846-86.

42 Kelemen, R. D., loc. cit.; Joerges, C.: Integration through Law and the Crisis of Law in Europe's Emergency, in: Chalmers, D., loc. cit., 299-338. 
the increasing politicisation of European issues. ${ }^{43}$ In that sense, its impact on the exercise of democratic governing powers in the multilevel European polity has remained politically latent. Whereas the piecemeal erosion of the institutions of non-liberal economies, industrial relations and welfare states is widely lamented in comparative political economy and welfare-state research, it is usually ascribed to the competitive pressures of economic globalisation and the dominance of a neoliberal Zeitgeist. By comparison, studies combining legal and politico-economic analyses with a focus on the liberalising effects of the judicial constitutionalization, expansion, and enforcement of "economic liberties" have remained quite rare. ${ }^{44}$

What is more widely recognised by now is the constraining effect on political democracy arising from excessive constitutionalization in general ${ }^{45}$ and from European constitutionalism in particular. ${ }^{46}$ This effect operates not only through actual interventions against specific national laws and institutions, but even more so through "non-decisions" 47 , that is, through the deterrent effect on political initiatives which, arguably, might violate supreme European law. The effect is greatly extended by the large penumbra of legal uncertainty associated with judicial legislation evolving through decisions in individual cases rather than through the general rules of European legislation. ${ }^{48}$

Given the constitutional supremacy and practical irreversibility of Treaty-based case law combined with the expansive dynamism of interest-driven litigation, there is a ratcheting effect of ever tighter legal constraints on non-liberal political action at the national and European levels. And quite apart from the liberalising transformation of non-liberal political economies, the consequence is a progressive narrowing of the action space and hence of the problem-solving capacity of democratic politics in the face of increasing external and internal challenges and

43 Hutter, S./ Grande, E./Kriesi, H. (ed.): Politicising Europe: Integration and Mass Politics, Cambridge, 2016.

44 See Höpner, M./ Schäfer, A.: Die Politische Ökonomie der europäischen Integration, Frankfurt a. M., 2008; Scharpf, F. W.: Assymmetry, loc. cit.; Rödl. F., loc. cit.; Werner, B., loc. cit.; Seikel, D.: Öffentlich-rechtliche Banken, loc. cit.; Barnard, C.: EU Employment Law, loc. cit.; Schmidt, S. K.: The European Court of Justice, loc. cit.; Blauberger, M./Schmidt, S. K.: The European Court of Justice and its Political Impact, in: West European Politics, 40/4 (2017). 907-918.

45 Bellamy, R.: Political Constitutionalism: A Republican Defence of the Constitutionality of Democracy, Cambridge, 2007.

46 Menéndez, A. J.: The Existential Crisis of the European Union, in: German Law Journal 14/5 ( 2013), 453-526; Grimm, D.: The democratic costs, loc. cit.; ders.: Zur Verfassung, loc. cit.; Garben, S.: Confronting the Competence Conundrum: Democratising the European Union through an Expansion of Its Legislative Powers, in: Oxford Journal of Legal Studies, 35/1 (2015), 55-89.

47 Bachrach, P./Baratz, M. S.: Two Faces of Power, in: American Political Science Review, 56/4 (1962), 947-952.

48 Schmidt, S. K.: Beyond Compliance: The Europeanization of Member States through Negative Integration and Legal Uncertainty, in: Journal of Comparative Policy Analysis, 10/3 (2008), 299-308; dies.: The European Court of Justice, loc. cit. 
crises. In other words, the judicial constitutionalization, extension, and enforcement of economic liberties has the effect of incapacitating democratic political action at a time when the multilevel European polity is challenged by the interaction of multiple crises that have the potential of undermining not only the democratic legitimacy, but also the political viability of government at the European and national levels. But what could be done about this?

\section{European solutions?}

Dieter Grimm has suggested a radical de-constitutionalization of the European Treaties. $^{49}$ In his view, a future Treaty of the European Union (TEU) should contain only rules of genuine constitutional status. These would have to constitute governing authorities at the European level, regulate their roles in the decision-making procedures of the Union, specify EU governing competences in relation to the member states, and define the fundamental principles, human rights, and citizen rights that are binding on European and national authorities. Most other rules in the present TFEU should then be downgraded to the status of ordinary or secondary European law.

This fundamental, in fact revolutionary revision of the Treaties would of course require the settlement of a vast number of difficult and controversial issues. If it could be achieved, it would indeed liberate political and legislative choices at the European level from the ever tighter and ever more rigid constitutional constraints of the overextended primary European law. As a consequence, it would rebalance the relationship between judicial and legislative authority in such a way that the judiciary would have to respect the primacy of potentially reversible policy choices made by politically accountable actors, but would nevertheless have the mandate and the authority to review political legislation on the basis of the institutional ground rules, basic human and citizen rights, and the fundamental principles of the European constitutional Treaty.

From the perspective of EU member states, however, the immediate effect of this fundamental reform would be quite limited. The present acquis of European law, even if much of it should lose constitutional status, would of course remain in force. And according to the general rule of federal constitutions, European law and its judicial interpretation would still override the law of the member states; it could still be invoked by individual and corporate litigants in national courts; and

49 Grimm, D.: The democratic costs, loc. cit.; ders.: Europe's Legitimacy Problem, loc. cit.; ders.: Zur Verfassung, loc. cit. 
it would still be policed by the Commission in infringement proceedings (Article 258 TFEU). Specific rules could, of course, now be relaxed or abolished through European legislation. But given the diversity of non-liberal national solutions and political preferences, individual governments would have to fight steep uphill battles trying to mobilise broad political support at the European level for removing a particular element of the acquis.

From the perspective of EU member states, therefore, the total revision of the constitutional architecture would be less important than a more limited solution that would prevent the judicial expansion of an "economic constitution" that is constraining national policy choices even in the absence of European legislation. For that, it would be sufficient to deny the status of directly enforceable subjective rights to the Treaty clauses that have been interpreted as guarantees of "economic liberties" and free movement rights. Moreover, as European legislation under these clauses should not be impeded, there is no reason to modify their substantive reach if there are procedural solutions that would achieve the intended effect. And since the judicial expansion of economic-liberties constraints is procedurally triggered by cases reaching the Court through preliminary references from national courts or through infringement proceedings launched by the Commission, effective procedural solutions should indeed be available. One possibility might be the insertion of a general clause at the beginning of Part Three of the TFEU stating that, under Titles I-IV, VI, and VII, litigation and infringement proceedings may only be based on regulations and directives adopted under Articles 289, 290, and 291 TFEU. $^{50}$ A similar clause might also be inserted with regard to Article 16 of the Charter of Fundamental Rights. By not including the prohibition of discrimination on the grounds of nationality under Article $18 \mathrm{TFEU}$ and Article 22 (2) of the Charter, however, the proposed amendments would still allow litigation and infringement proceedings challenging protectionist measures impeding the access of foreign suppliers or consumers to national markets. ${ }^{51}$

If this or a similar solution were to be adopted, there is no reason to fear that it could destroy the single market. The huge body of European legislation on economic integration, much of it codifying the economic liberties case law, would of course remain in place. From the perspective of member governments, therefore,

50 Thus, Commission directives adopted under Article 106 (3) TFEU would not qualify.

51 This would amount to a return to the Court's case law before the Dassonville and Cassis decisions moved from intervening against protectionist discrimination to intervention against all national rules or practices "that are capable of hindering, directly or indirectly, actually or potentially" the exercise of a Treaty-based liberty. 
the proposal would make most of a difference in policy areas like capital taxation, industrial relations, corporate governance, social and public services, and public infrastructure, where the diversity of national traditions, institutions, and preferences has so far impeded effective European legislation. ${ }^{52}$ Where European legislation does exist, it could now be changed - but it would still be hard to mobilise European majorities for issues that may have political salience in only one or a few member states.

To deal with such constellations, I had proposed in a previous article a procedure that would allow member states to ask for politically controlled individual optouts from the European acquis. Under that procedure, a member state should notify the Commission of a national legislative initiative that would conflict with existing European legislation. After being reviewed in light of the issues at stake in the particular case and of present political preferences, such initiatives could be denied by a vote of Council. In effect, the possibility of re-examining the acquis on a case-by-case basis should result in a more fine-grained pattern of European law that is based on a political assessment of the actual need for Europe-wide uniformity, and it should eventually limit the body of binding European law to rules that serve a positive European purpose and that have the political support of current legislative majorities at the European level.

From the perspective of European legislation, these proposals would change the function of economic liberties: instead of displacing European legislation, they would empower it to define (and re-define) the wider or narrower limits of competitive markets in the political economies of the European Union. And where the effective boundaries between markets, civil society, and the state are not defined by political legislation at the European level, the competence would revert to political choices at the national level. In short, these changes should remove the judicially defined constraints of a European economic constitution by empowering legislative action at the European and national levels.

\section{The Joint Decision Trap}

But while these reforms would enlarge the action space for democratic policy choices at the national level, their effect on European legislation might be quite limited. As was pointed out some time ago, the manifest asymmetry of negative and positive integration is a consequence not only of the "negative" effectiveness of 
legal constraints on national action, but also of the political weakness of "positive integration" and re-regulation through legislative action at the European level. ${ }^{53}$

\section{The problem}

The problem, in a nutshell, has been and still is the "Joint Decision Trap", i. e., the fact that European legislation must be adopted in a multiple-veto (jointdecision) system. ${ }^{54}$ Under the present rules of the "Community Method," the process must start with the Commission making a proposal that a majority - but generally a consensus - of the College of Commissioners has agreed upon ${ }^{55}$; and it cannot succeed without the agreement of a qualified majority - but generally a consensus - of governments in the Council and an absolute majority in the European Parliament (EP). But as successive rounds of enlargement have not only increased the number of member states from the Original Six to twelve in the mid1980s and now to twenty-eight (or rather twenty-seven), they have also dramatically increased differences among them in size, economic development, social and political cultures and institutions, geo-political location, and political preferences.

National governments in the Council are of course open to the influences of powerful national interest. At the same time, the specialised directorates in the Commission are highly accessible to the inputs of economically and organisationally powerful interest organisations ${ }^{56}$, just as committees and party families in the European Parliament are responsive to yet other combinations of economic and civil-society lobbyists. ${ }^{57}$ But whereas in national democracies plural interest positions may at times be overwhelmed by the election-based force of majoritarian politics, European legislation cannot draw on such pro-active power resources against the accumulation of defensive influences exercised at the multiple institutional veto positions.

This explains why judicial legislation and "integration through law" ly welcomed as a non-political "bypass",59 when legislative harmonisation had stagnated in the 1970s; and it also explains the quantitative importance of legisla-

53 Scharpf, F. W.: Governing in Europe, loc. cit., ch. 3.

54 Scharpf, $F . W$.: The Joint Decision Trap: Lessons from German Federalism and European Integration, in: Public Administration Review, 66 (1988), 239-278; Tsebelis, G.: Veto Players: How Political Institutions Work, Princeton, 2002.

55 Hartlapp, M./Metz, J./Rauh, C.: Which Policy for Europe? Power and Conflict inside the European Commission, Oxford, 2014.

56 Eising, R.: Interest Groups in EU Policy-Making. In: Living Reviews, in European Governance, $3 / 4$ (2008); Hartlapp, M. et al., loc. cit.

57 Coen, D./Richardson, J. (ed.): Lobbying the European Union: Institutions, Actors, and Issues, Oxford, 2009.

58 Cappelletti, $M$. et al., loc. cit.

59 Genschel, P., loc. cit. 
tion that appears politically uncontroversial because it merely seems to codify the Treaty-based case law. ${ }^{60}$ Beyond that, the dynamic expansion of European legislation in the fields of public health, work safety, and environmental and consumer protection (Art. 114 TFEU) is to a large extent explained by the interest of all governments and industries in the common product standards that would ensure access to the wider European market. ${ }^{61}$

Moreover, even in fields where political interests do not initially converge, research has identified a variety of bargaining strategies going beyond the "classical" methods of side payments and package deals to facilitate agreement in multi-actor negotiations. ${ }^{62}$ These include the Commission's use of legal instruments to divide and undermine national veto positions ${ }^{63}$, and its resort to Treaty-based games, arena shifting, and procedural "subterfuges" that allow political conflict to be reduced or avoided. ${ }^{64}$ In actual practice, therefore, the promoters of European legislation will often find ways and means to achieve solutions exceeding agreement on the lowest common denominator. ${ }^{65}$ But though there is more effective European legislation than a simple veto-player model would suggest, the rules of the Community Method still imply a need to accommodate a wide variety of national, institutional, economic, and partisan veto players. As a consequence, consensual European legislation is unlikely to violate any of the politically salient interests represented by national governments or any of the economic and civil-society interests that have privileged access to Commission directorates or to committees and party groups in the EP.

From a liberal perspective, of course, the need for consensus and the incapacity to inflict pareto-inferior outcomes on any veto player may be seen as a normatively very attractive characteristic of European legislation. Moreover, in calm and economically favourable periods, the "permissive consensus" of European publics was not seriously challenged by the absence of "public" European politics and by the primacy of non-political judicial legislation and bureaucratic regulation in promoting ever more economic integration. In any case, as long as democratically accountable national governments would loyally comply with the ever expanding

60 Martinsen, D. S., loc. cit.

61 Scharpf, F. W.: Governing in Europe, loc. cit., 91-101.

62 Scharpf, F. W.: Games Real Actors Play: Actor-Centered Institutionalism in Policy Research, Boulder, 1997, ch. 6.

63 Schmidt, S. K.: Law Making, loc. cit.

64 Héritier, A.: Policy-Making by Subterfuge: Interest Accommodation, Innovation and Substitute Democratic Legitimation in Europe, in: Journal of European Public Policy, 4/2 (1997), 171-189.

65 Héritier, A.: Policy-Making and Diversity in Europe: Escaping Deadlock, Cambridge, 1999; Scharpf, $F$. W.: The JDT Model: Context and Extensions, in: Falkner, G., loc. cit., 217-236. 
body of supranational European law, academic interest in the "European democratic deficit" was not matched by politically salient public concerns. ${ }^{66}$

But when times turned rough during the international financial and economic crises after 2008, the constitutionalised Maastricht rules prevented effective policy responses, while the procedures of unanimous Treaty revision foreclosed any attempt to change these rules in order to allow discretionary political and effective legislative responses to the crisis. In its first serious challenge under the Maastricht and Lisbon Treaties, therefore, European legislation by the Community Method was incapacitated by an overly rigid constitutional straightjacket. Faced with the prospect of massive government failure, therefore, European and national leaders have tried, and are still trying, to gain more room for manoeuvre by fudging the constitutional constraints - whose legal force they cannot challenge as long as they are unable to agree on formal changes. In order to gain more flexibility, they have widened the discretionary powers of non-accountable supranational actors and relied on conflict resolution through intergovernmental negotiations outside of the Treaty and under the influence of asymmetric bargaining powers.

\section{Supranational and intergovernmental flexibility}

The first of these options is exemplified by the extension of the discretionary powers of the European Central Bank (ECB). Since its political independence is more securely institutionalised than that of any other central bank, it has been able to interpret the narrow mandate defined by the Maastricht Treaty very broadly. Hence, on the verge of another euro crisis in the summer of 2012, President Draghi's dramatic announcement of unconventional measures was effective in stopping speculative attacks on some southern states. And in the face of serious ultra vires challenges, the ECJ's Gauweiler decision ${ }^{67}$ affirmed that the Bank was not overstepping its narrow mandate of securing price stability through monetary (rather than economic) policy measures. Yet, even when pushed to its limits, monetary policy alone has been unable to stimulate economic growth in the Eurozone. And the more the Bank's discretionary measures appear to be straining its Treaty-defined narrow mandate, the more they are also pushing against the boundaries of the limited legitimacy of politically non-accountable authority.

In any case, the ECB's autonomous powers can only address a narrow range of problems, and even there the Bank's effectiveness is constrained by the lack of

Scharpf, F. W: Legitimacy Intermediation in the Multilevel European Polity and its Collapse in the Euro Crisis, in: Armingeon, K. (ed.): Staatstätigkeiten, Parteien und Demokratie, Wiesbaden, 2013, 567-596. 
complementary action in fiscal policy. ${ }^{68}$ Similarly, the Juncker Commission is straining against its narrowly defined legislative mandate under the Excessive Deficit Procedure by postponing the enforcement of deficit rules against member states in economic and political distress. But while this exercise of "discretion by stealth" may soften the negative impact of rigid rules, it also challenges the narrow boundaries of the Commission's legitimacy and its difficult relationship with the Council. ${ }^{69}$ In short, the capacity of politically non-accountable supranational authorities to provide technocratic-authoritarian solutions to urgent problems is limited by their pre-existing constitutional and legislative mandates which under present political conditions resist formal amendment. And though these constraints may be fudged or widened through actual practices that may find the support of questionable judicial interpretations, their credibility and effectiveness is reduced by widely shared doubts of their legitimacy.

Such constraints seem to be absent when the exit from the Community Method is achieved through intergovernmental agreement - a mode of policy-making whose importance is said to have generally increased in the post-Maastricht period. ${ }^{70}$ But though intergovernmental action seems to have dominated in recent European responses to crises in the Ukraine, to the Euro crisis, and the refugee crisis, there is a theoretical puzzle: if high consensus requirements explain the lack of effective political action under the rules of the Community Method, why should one think that problem-solving effectiveness is increased by switching to bargaining among the governments involved - where the decision rule is generally unanimity or, at best, consensus?

In approaching an answer, it seems useful to distinguish between intergovernmental policy-making within and outside the institutional framework of the European Treaties. In the former case, bargaining takes place in a "compulsory negotiation system" ${ }^{71}$ in which unilateral action is ruled out and objectives can only be achieved through (near) universal agreement. Outside of the EU framework, in contrast, negotiations are "voluntary" in the sense that participation is not institutionally compelled, that agreement may be reached through the em-

68 De Grauwe, P.: The Political Economy of the Euro, in: Annual Review of Political Science, 16/1 (2013), 153-170.

69 Schmidt, V. A.: The Eurozone's Crisis of Democratic Legitimacy: Can the EU Rebuild Public Trust and Support for European Economic Integration?, in: European Economy Discussion Paper 15 (2015); Seikel, D.: Öffentlich-rechtliche Banken, loc. cit.

70 Bickerton, C. J./Hodson, D./Puetter, U.: The New Intergovernmentalism: European Integration in the Post-Maastricht Era, in: Journal of Common Market Studies, 53/4 (2015), 703-722.

71 Scharpf, F. W.: Games, loc. cit., 143-145. 
ployment of all available bargaining strategies and of asymmetric bargaining powers, and that outcomes are binding only for those who agreed.

In matters not regulated by the existing Treaties, therefore, "coalitions of the willing" may commit themselves to common action, while others may prefer to stay outside. The Schengen Agreement is a celebrated example of how European integration could be advanced outside of - and subsequently integrated into - the legal framework of the Treaties. Similarly, the Fiscal Compact was an outcome of "voluntary" (and quite asymmetric) negotiations in order to avoid a British veto in Treaty amendment procedures. But the ECJ's obvious difficulty in justifying the international treaty creating the European Stability Mechanism (ESM) in its Pringle ${ }^{72}$ decision ${ }^{73}$ suggests that the option of intergovernmental action outside of the Treaties in areas that are arguably within the competence of the Union will not be generally available - except under the constraining rules of "enhanced Cooperation" (Articles 20 TEU, 326-334 TFEU).

If decisions have to be reached within the institutional framework of the EU, and if the Community Method appears blocked by disagreement in the Council, it is nevertheless true that intergovernmental agreement is often reached at summit meetings in less formal bilateral or multilateral talks among the heads of state and government. ${ }^{74}$ One obvious reason is the greater opportunity at the higher hierarchical level for inter-sectoral package deals. Beyond that, leaders have the political authority to accept concessions that lower-level negotiators would have to reject. Moreover, the group dynamics and the drama of summit meetings may also provide an emotional and political push that increases the perceived importance of reaching a common European solution relative to the national concessions required.

What may matter more from a theoretical perspective, however, is the lesser role of supranational actors and of formal decision rules - and the increasing importance of power asymmetries among EU member states. On a summit, the Commission's role of agenda setter will not constrain political choices, ${ }^{75}$ and the

72 Case C-370/12

73 De Witte, B./Beukers, T.: The Court of Justice Approves the Creation of the European Stability Mechanism outside the EU Legal Order: Pringle, in: Common Market Law Review, 50 (2013), 805-848.

74 Hartlapp, M.: Organizing Exits from the Joint-Decision Trap? Cross-Sectoral (Non-)Coordination in the European Union, in: Falkner, G., loc. cit., 181-198.

75 Moreover, mandates of the European Council will not only short-circuit the processes through which the Commission comes to launch legislative initiatives, but may also immunize these initiatives against close political scrutiny under the Community Method - as seems to have happened with the EU regulation banning incandescent household bulbs (Deters 2015). 
European Parliament cannot directly oppose intergovernmental compromises. Moreover, the informal "consensus" of summit agreements will bypass the decision rules which otherwise define the relative voting power of national governments in the Council. The formal voting weights assigned by these rules are meant to create an "artificial balance of powers" among member state governments that moderates the effect of differences in population size - and that takes no account at all of other differences in national power resources. ${ }^{76}$ This is why small EU member states have always looked to the Commission and formal European institutions to protect them from their bigger neighbours ${ }^{77}$; and it is also why Andrew Moravcsik's "liberal intergovernmentalism" has been wrong in trying to explain all European policy outcomes by reference to the size and economic potential of member states.

This is not meant to imply that differences in national power resources are fully neutralised by institutional voting rules. But it suggests that their importance increases as formal voting procedures are bypassed by informal intergovernmental bargaining. ${ }^{79}$ In the context of the Euro crisis of 2010, for instance, and after "exit" from the Monetary Union had been ruled out by general consent, the dependence of financially challenged states on intergovernmental credits, and the position of Germany as the largest creditor state, had indeed generated an extremely asymmetric distribution of bargaining power that allowed the imposition of "conditionalities" and Euro rules favouring the structural conditions of "Northern" political economies. ${ }^{80}$ Moreover, the "coercive power" of financial dependence may also have favoured the acceptance of the "ideational" German

76 That is why it matters that the one country, one vote-rule of the ECB Governing Council differs significantly from the weighted votes reflecting shareholder contributions on the ESM Board of Governors.

77 Panke, D.: Small States in the European Union: Structural Disadvantages in EU Policy-Making and Counter-Strategies, in: Journal of European Public Policy, 17/6 (2010), 799-817.

78 Moravcsik, A.: Preferences and Power in the European Community: A Liberal Intergovernmentalist Approach, in: Journal of Common Market Studies, 31/4 (1993), 473-524; ders.: The Choice for Europe: Social Purpose and State Power from Messina to Maastricht, Ithaca, 1998; Garrett, G./Tsebelis, G.: An Institutional Critique of Intergovernmentalism, in: International Organization 50/2 (1996), 296-299.

79 It needs to be understood, moreover, that what matters is not differences in power resources as such, but issue-specific differences in bargaining power. This is the common conclusion of power-dependence theory (Emerson, R. M. Power-Dependence Relations, in: American Sociological Review 27/1 (1962), 31-41), resource-dependence theory (Pfeffer, J./Salancik, G. R.: The External Control of Organizations: A Resource Dependence Perspective, New York, 1978), and Nash bargaining theory (Nash, J.: The Bargaining Problem, in: Econometrica 18/2 (1950), 155-162): power is a relational and issue-specific concept; and bargaining power is defined by the relative costs of non-agreement for individual participants.

80 And once these rules were in place, the attempt by the Greek government to have them changed in 2015 lacked the asymmetric bargaining power that would have been needed to bring about their revision (Tsebelis, G.: Lessons from the Greek Crisis. In: Journal of European Public Policy, 23/1 (2016), 25-41); see also Tsoukalis, L.: In Defence of Europe: Can the European Project Be Saved?, Oxford, 2016; Scharpf, F. W.: Forced Structural Convergence, loc. cit. 
precepts of fiscal austerity and supply-side reforms. ${ }^{81}$ In September 2015, however, when Germany came to ask for the geographic redistribution of refugees, the power-dependence relationship was reversed, and instead of contributing to its ideational power, the relative strength of the German economy now weakened the appeal to European solidarity and burden sharing. ${ }^{82}$

In short, moving from the formal constraints of the Community Method to informal intergovernmental bargaining may indeed facilitate European action by exploiting situation- and issue-specific asymmetries of bargaining power. But of course the existence of power asymmetries among EU member states that happen to favour effective European action cannot be taken for granted. Hence, it also seems unlikely that the "new intergovernmentalism" 83 might point the way toward a general remedy for the problem-solving deficits arising from the Community Method's limited capacity for effective political action.

In effect, therefore, neither supranational authority nor intergovernmental bargaining seem to provide generally viable and legitimate solutions in policy areas where effective political action by the Community Methods is blocked by a lack of consensus. Under these conditions, the appropriate response in normative political and constitutional theory would be to restore the problem-solving capacity of EU member states - which might require European legislation that disables the binding force of the acquis in specific matters. ${ }^{84}$

But even though the Treaties ought to recognise a general principle according to which the member states must be allowed to deal with problems that cannot be politically resolved on the European level, that could not be the end of the matter: Quite obviously in several (though not all) of the presently most threatening crises (and sometimes as a consequence of prior European action), purely national solutions would be ineffective even for the large member states like Germany

81 Carstensen, M. B./ Schmidt, V. A.: Power and Changing Modes of Governance in the Euro Crisis, Workshop paper, Brussels, 2016; dies.: Power through, over and in Ideas: Conceptualizing Ideational Power in Discursive Institutionalism, in: Journal of European Public Policy, 23/3 (2016), 318-337; Matthijs, M: Powerful Rules Governing the Euro: The Perverse Logic of German Ideas, in: Journal of European Public Policy, 23/3 (2016), 375-391.

82 Resorting then to formal decision rules, the Commission managed to have a regular Council Decision adopted that defined quotas for the relocation of 120,000 refugees from Greece and Italy. But though the rule adopted by qualified majority in the Council is legally binding for all member states, its legitimacy is challenged by governments in Central and Eastern Europe, and implementation remains minimal (Börzel, T. A.: From EU Governance of Crisis to Crisis of EU Governance: Regulatory Failure, Redistributive Conflict and Eurosceptic Publics, in: Journal of Common Market Studies 54/1 (2016), 8-31).

83 Bickerton, $C$, loc. cit.

84 Under present rules, of course, such enabling legislation might also be blocked by parties benefiting from the status quo. 
or France, and simply unavailable for most of the smaller European states. Even from a purely national perspective, therefore, the citizens of European polities have become dependent on effective European action for the performance of some of the most basic state functions. In other words, we must presume the existence of a good deal of actual, and even more potential, political demand for European solutions that is frustrated by the present weakness of European capacities for effective political action.

\section{Activating the political politics of European legislation}

The question then is whether and how the potential political demand for European solutions could be mobilised as a source of political energy that will activate the problem-solving capacity of European legislation. Under present conditions, this cannot be the result of bottom-up processes alone - which, without effective links into European decision processes, are more likely to generate frustration and alienation rather than mobilisation for effective political action. As a minimum, effective mobilization presupposes that politically salient issues have a chance of being placed on the European legislative agenda.

As an important first step, that suggests that the Commission's monopoly of legislative initiatives should be relaxed. In exceptional cases, to be sure, the European Council may, by intergovernmental consensus, mandate the development of a particular policy initiative. Beyond that, however, problems, policy goals, and potential solutions that are not taken up by the Commission will remain excluded from the European policy-making process. And though the Commission President may have a few political priorities, the Commission's gatekeeping function is primarily exercised by the specialised Directorates General and shaped by the distinct technical orientations and political sensitivities of their professional staffs. ${ }^{85}$ Allowing legislative initiatives to be introduced by governments in the Council and by factions of the European Parliament would help to activate the politics of European legislation by widening the range of policy choices for which political support and against which political opposition could be mobilised at national and European levels.

But that would not be enough. Under the rules of the Community Method, serious political actors could hardly be expected to waste their political capital on initiatives that everybody considers hopeless. Hence, by the "rule of anticipated reaction", self-censorship will continue to keep issues off the European agenda that 
have no chance of succeeding under the consensus requirements of the European multiple-veto system. That would be different, if decision rules, which presently have an extreme bias in favour of the status quo, would create a more level playing field between the promoters of policy change and the defenders on non-action which could be achieved by allowing European legislation to be adopted by plurality votes in the Council and the Parliament. If such rules were in place, legislation in the European Union would approximate the conditions of politically integrated federal states with a bicameral parliament. This would surely increase the capacity for political action at the European level, and it would also raise the stakes in European politics - and hence the political salience of European policy choices. But as the Union is not a politically integrated federal state, European legislation by majority rule would also provoke fundamental concerns of democratic legitimacy as well as quasi-metaphysical controversies over the existence of a European demos that could only be met if the move to majority rule were combined with the right to national opt-outs. And that requires a more thorough discussion.

\section{From legitimating consensus to legitimate majority rule?}

Originally, European legislation had required the unanimous agreement of national governments in the Council. At that time, its political legitimacy was thought to rest on the Roman-law consensus principle of volenti non fit iniuria combined with the assumption that politically accountable national governments were authorised and legitimated to represent the interests and preferences of their peoples in external interactions. That link was weakened when the Single European Act of 1987 introduced qualified majority voting (QMV) in the Council on issues of economic integration - which then provoked academic and some public concern over a European democratic deficit. In response, the rights of the European Parliament were progressively extended and, in combination with the extension of QMV in the Council, generalised in the rules of the "Community Method", alias the "ordinary legislative procedure" (Article 289 TFEU). At the same time, the Lisbon Treaty postulated a dual legitimacy base for the EU as a "representative democracy" - combining the direct representation of citizens in the European Parliament and their indirect representation through democratically accountable governments in the European Council and the Council (Article 10 TEU).

In practice, nevertheless, the Council tries to avoid decisions by QMV, continuing to search for consensus solutions. And even if unanimity is not achieved, the formal quorum is so high, and blocking minorities are so small, that the Community Method in practice can still claim legitimacy by invoking the consensus principle. 
If that should be abandoned in the search for greater capacities for European political action, however, discussion would, for the first time, have to address the normative legitimacy and political acceptability of majority rule at the European level.

\section{Factual presuppositions of legitimate majority rule}

Constitutional democracies at the national level take majority rule for granted, but they limit its domain through the rule of law and the constitutional protection of (individual) human and citizen rights and of the (collective) rights of specific minority groups. Beyond that, they differ in the extent to which the straightforward exercise of majority rule is further impeded by institutional "checks and balances", super-majoritarian voting rules and multiple veto positions that are supposed to provide protection against the "tyranny of the majority" or "populist democracy". ${ }^{86}$ In this regard, the EU's Community Method is surely located at the extreme end of Arend Lijphart's ${ }^{87}$ comparative classification of majoritarian and consensus democracies. Hence, if a reduction of its consensus requirements is considered, one needs to examine the legitimating arguments and assumptions justifying the exercise of majority rule in majoritarian democracies at the national level.

The theoretical starting point is, again, the interest-based consensus principle, or its reverse implication: if no harm is done, consensus may be presumed. Hence, the need for justification is low for policies that are roughly compatible with the interests and preferences of those affected, and it is highest for policies that impose unequal and uncompensated sacrifices or violate the highly salient values or preferences of a minority. In a next step, this distinction is linked to assumed differences in the interests, values and preferences of the polity's membership: in homogeneous and egalitarian political communities, it seems plausible to believe that majoritarian policy choices, even though they are not preferred by the opposition, will not generally violate the highly salient concerns of the minority. ${ }^{88}$ In

86 Riker, W. H.: Liberalism against Populism: A Confrontation between the Theory of Democracy and the Theory of Social Choice, San Francisco, 1982.

87 Lijphart, A.: Patterns of Democracy: Government Forms and Performance in Thirty-Six Countries, New Haven, 1999, 42-47.

88 This point is conceded even by normative political theorists starting from liberal premises that have no place for the "communitarian" concept of a socially or culturally constituted demos (Christiano, $T$.: The Rule of the Many: Fundamental Issues in Democratic Theory, Boulder, 1996; McGann, A.: The Logic of Democracy: Reconciling Equality, Deliberation, and Minority Protection, Ann Arbor, 2006). In their view, democracy implies majority rule (and proportional elections), because only majority rule is compatible with the fundamental principle of political equality. Nevertheless, the legitimacy of democratic rule presupposes a common world in which "the fulfillment of all or nearly all of the fundamental interests of each person are connected with the fulfillment of all or nearly all of the fundamental interests of every other person" (Christiano, T.: The Constitution of Equality: Democratic Authority and Its Limits, Oxford, 2008, 80). It is the rough equality in the way constituents are affected that justifies 
socially divided and unequal societies, in contrast, majority rule is likely to be more distrusted and the minority's tolerance for policy choices violating its interests or preferences is likely to be lower - which is why checks and balances and supra-majoritarian voting rules are often considered necessary to ensure the cohesion of "consociational democracies".

Even in relatively homogeneous societies, however, the interest-based consensus principle would not justify the imposition of uncompensated sacrifices on parts of the membership. It is in reference to such "hard" policy choices that arguments legitimating majority rule then tend to invoke demos-related concepts. Postulating a "thick" collective identity, variously based on claims of ethnic, linguistic, or sociocultural homogeneity, common history, common normative commitments and values, or common aspirations and perils ${ }^{89}$, such arguments presuppose shared attitudes like solidarity or patriotism that imply a willingness (or a socially stabilised obligation) to accept personal sacrifices in the interest of (other members of) the political community. In politically integrated communities where such attitudes may be taken for granted, they will greatly expand the action space of democratically legitimate majority rule. But even in internally divided societies, the normative salience of existing cleavages may be suppressed, and the appeal to a common identity may gain the force of normative compulsion if the polity itself is (seen to be) confronted with an external threat that challenges its viability. ${ }^{90}$

When these empirical preconditions are taken into consideration, they certainly do not support demos-based justifications of majority rule in the European Union. The ethnic, linguistic, cultural, institutional, economic, and political diversity of the "peoples of Europe" far exceeds that of majoritarian constitutional democracies. Collective identity among its heterogeneous constituents is at best

equal participation and majoritarian decisions. These real-world preconditions of political equality and democratic majority rule are presently not seen to exist beyond the boundaries of the modern state (Christiano, T.: Equality, loc. cit., 83; ders.: Democratic Legitimacy and International Institutions, in: Besson, S./Tasioulas, J. (ed.): The Philosophy of International Law, Oxford, 2010, 119-137).

89 Weiler, J.: After Maastricht: Community Legitimacy in Post-1992 Europe, in: Adams, W. J. (ed.): Singular Europe: Economy and Polity of the European Community after 1992, Ann Arbor, 1992, 11 41; Miller, D.: On Nationality. Oxford, 1995; Habermas, J.: Constitutional Democracy: A Paradoxical Union of Contradictory Principles?, in: Political Theory 29/6 (2001), 766-781; Scherz, A.: The Legitimacy of the Demos: Who Should Be Included in the Demos and on What Grounds?, in: Living Reviews in Democracy (2013), 1-14.

90 At the onset of the First World War, Emperor William the Second of Germany famously declared: "Ich kenne keine Parteien mehr; ich kenne nur noch Deutsche" ("I don't know parties any more, I only know Germans"). And in France, "la union sacrée" expressed the same imposition of an internal political truce in the face of war. 
quite thin. ${ }^{91}$ And far from stimulating pan-European patriotism, the serious external challenges the Union is now facing in Ukraine and in the refugee crisis seem to be deepening existing cleavages instead. ${ }^{92}$ In other words, input-oriented political legitimacy in the Union continues to depend on the consensus principle.

The normative and institutional implications of this conclusion are spelled out by "republican" political theorists in the increasingly influential literature promoting the normative concept of a European demoi-cracy. ${ }^{93}$ These authors are acutely aware of the erosion of democratic self-government in EU member states and their increasing domination by European constraints and interventions that, at present, cannot be democratically legitimated at the European level. From their perspective, democratic legitimacy can only be derived from the "peoples of Europe," and the Union itself must be interpreted as the cooperative association of a plurality of European "states' peoples" organised as democratic member states. These will have to accept the principle of "mutual recognition." In addition, they must avoid negative externalities of national action and pursue common objectives through either voluntary intergovernmental coordination or "two-level contracts" among national governments and between these and their national constituencies. ${ }^{94}$

If put into practice, an institutional framework reflecting the principles of demoicracy might indeed reduce present legal constraints on democratic self-

91 Such differences are not written in stone, of course. The literature on state building, political integration, and political pluralism has emphasized not only the importance of "cross-cutting cleavages," but also the historical processes that have mitigated the salience of existing divisions and the importance of "overlapping interests" that could legitimate majority decisions in pluralist political communities (Lipset, S. M.: Political Man: The Social Bases of Politics, Garden City, 1960; Rokkan, S.: Geography, Religion and Social Class: Cross-Cutting Cleavages in Norwegian Politics, in: Rokkan, S./Lipset, S. M. (ed.): Party Systems and Voter Alignment: Cross-National Perspectives, New York, 1967, 367-444; Truman, D.: The Governmental Process: Political Interests and Public Opinion, New York, 1951). For the European level, however, even optimistic assessments before the present crises would at best have anticipated an evolution toward "consensual" or "consociational democracy," but certainly not toward legitimate majority rule (Lijphart, A., loc. cit.; Andeweg R. B.: Consociational Democracy, in: Annual Review of Political Science, 3 (2000), 509-536; Schmidt, M. G.: The Consociational State: Hypotheses Regarding the Political Structure and Potential for Democratization of the European Union, in: Acta Politica, 37/1-2 (2002), 213-227).

92 Börzel, T. A., loc. cit.

93 E.g. Nicolaidis, $K$ : The New Constitution as European "Demoi-cracy"?, in: Critical Review of International Social and Political Philosophy, 7/1 (2004), 76-93; ders.: The Idea of European Demoicracy, in: Dickson, J./Eleftheriadis, P. (ed.): Philosophical Foundations of EU Law, Oxford, 2012, 247-274; Chevenal, F./Schimmelfennig, F.: The Case for Demoicracy in the European Union, in: Journal of Common Market Studies, 51/2 (2013), 334-350; Bellamy, R.: “An Ever Closer Union among the Peoples of Europe": Republican Intergovernmentalism and Democratic Representation within the EU, in: Journal of European Integration, Special Issue 35/5 (2013), 499-516; Lindseth, P.: Equilibrium, Demoi-cracy, and Delegation in the Crisis of European Integration, in: German Law Journal, 15/4 (2014), 529-568.

94 Weale, A.: Citizenship in Europe and the Logic of Two-Level Political Contracts, in: German Law Journal, 15/5 (2014), 867-881; Bellamy, R./Weale, A.: Political Legitimacy and European Monetary Union: Contracts, Constitutionalism and the Normative Logic of Two-Level Games, in: Journal of European Public Policy 22/2 (2015), 257-274. 
government at the national level. ${ }^{95}$ However, its capacity for dealing with conflicting national interests and preferences in the face of crises and challenges requiring effective political action at the European level appears to be even lower than it is at present. From what has been said, therefore, it would follow that the consensual ground rules of the Community Method may indeed represent the maximum of legitimate capacity for political action that can be achieved by the European Union under present conditions.

If that were the last words, however, the European Union would be left with a stark choice: when faced with challenges calling for effective European action under conditions of severe political disagreement, consensual decision making would fail the test of output legitimacy, whereas majority rule would lack democratic legitimacy under no-demos conditions. In this predicament, the Union has tended to rely on non-political supranational authority or on the exercise of asymmetric intergovernmental power - both of which lack democratic legitimacy and are limited in their problem-solving capacity. But is this conclusion inevitable?

\section{Deliberative democracy and majority vote}

In recent contributions to a possible theory of democracy beyond the nationstate, static arguments defining the structural preconditions or of majoritarian democracy have been replaced by dynamic approaches suggesting that democratic legitimacy may be generated through political processes themselves. ${ }^{96}$ In line with a general "constructivist turn" in social and political science, the basic assumption is that "socially constructed" interest and value positions do not need to be taken as given, but may change under the influence of empirical and normative arguments 97 - which resonates with the liberal ideal of "government by discussion" $" 98$. In the present normative discussion, the basic approach is represented by theories of discursive or deliberative democracy ${ }^{99}$ that combine Jürgen

95 But see Sievers, J./Schmidt, S. K.: Squaring the Circle with Mutual Recognition? Demoi-cratic Governance in Practice, in: Journal of European Public Policy 22/1 (2015), 112-128.

96 E.g. Archibugi, D./Held, D. (ed.): Cosmopolitan Democracy: An Agenda for a New World Order, Cambridge, 1995; Nanz, P./Steffek, J.: Legitimation durch Deliberation? Die Rolle der Zivilgesellschaft in der supranationalen Politik, in: Knodt, M./Finke, B. (ed.): Europäische Zivilgesellschaft: Konzepte, Akteure, Strategien, Wiesbaden, 2005, 79-102; Archibugi, D./Koenig-Archibugi, M./Marchetti, $R$. (ed.): Global Democracy: Normative and Empirical Perspectives, Cambridge, 2011.

97 Müller, H.: Arguing, Bargaining and All That: Communicative Action, Rationalist Theory and the Logic of Appropriateness in International Relations, in: European Journal of International Relations $10 / 3$ (2004), 395-435.

98 Habermas, J.: Strukturwandel der Öffentlichkeit: Untersuchungen zu einer Kategorie der bürgerlichen Gesellschaft, Neuwied, 1962.

99 Dryzek, J. S.: Discursive Democracy: Politics, Policy, and Political Science, Cambridge, 1990; Bohman, J.: Public Deliberation: Pluralism, Complexity, and Democracy, Cambridge, MA, 1996. 
Habermas's theory of communicative action ${ }^{100}$ with an epistemic version of democratic theory. The theory of communicative action postulates that, in principle and under ideal circumstances, truth-oriented exchanges of arguments are capable of attaining unforced agreement, not only on issues of fact, but also in normative controversies. In the political sphere, therefore, ideal deliberative processes should also be able to resolve conflicts of political interests and preferences through general agreement on the empirically and normatively optimal solution. In that sense, the ideal of deliberative democracy is meant to provide a radically consensus-oriented version of political legitimacy that - because universal consensus defines the common good - would also avoid any tension between output-oriented and input-oriented democratic legitimacy.

As deliberation can be practiced in any setting - local, national, global, scientific, bureaucratic, or political - academic interest mainly focuses on the ideal preconditions for truth-oriented and non-strategic discussion and unforced agreement, and on their approximation in experimental and empirical settings. ${ }^{101}$ To qualify as a plausible theory of political democracy, however, deliberative democracy depends on further assumptions. Thus Habermas postulates the existence of a "public sphere" 102 with universal access in which all social and political propositions, concerns, and demands may be freely articulated and publicly debated in open-ended discourses. The need for binding decisions is to be accommodated at a second, institutional level, where deliberations are focused on the resolution of specific legal or political issues. To satisfy democratic requirements, however, institutionalised deliberation must continue to be immersed in, informed by, transparent to, and publicly justified in relation to the ongoing stream of informal discussion in the public sphere.

Decision-oriented deliberations, however, cannot be open-ended; they must be terminated at some point even if full consensus has not yet been reached. And in that case, Habermas, following Joshua Cohen, suggests that decisions are to be reached by majority vote. The rule is justified if the vote itself is part of the ongoing deliberative praxis. It is then not a free-standing, voluntarist decision, but a

100 Habermas, J.: Theorie des kommunikativen Handelns, Frankfurt a. M., 1984.

101 Grönlund, K./Bächtiger, A./Setälä, M. (ed.): Deliberative Mini-Publics: Involving Citizens in the Democratic Process, Sussex, 2014; Baccaro, L./Bächtiger, A./Deville, M.: Small Differences That Matter: The Impact of Discussion Modalities on Deliberative Outcomes, in: British Journal of Political Science, 46/3 (2016), 551-566.

102 Habermas, J.: Faktizität und Geltung: Beiträge zur Diskurstheorie des Rechts und des demokratischen Rechtsstaats, Frankfurt a. M., 1992, ch. VII; ders.: Hat die Demokratie noch eine epistemische Funktion?, in: ders. (ed.): Ach, Europa: Kleine politische Schriften XI, Frankfurt a. M., 2008, 138-191. 
reflection of the current state of truth-oriented exchanges of information and arguments - which justifies the conclusion that "the fallible opinion of the majority will for the time being provide the rational basis of common praxis." ${ }^{103}$ Thus, if the process as a whole is truth-oriented, the majority vote appears as a legitimate shortcut that approximates, for the time being, a consensual solution. ${ }^{104}$ In contrast to demos-oriented legitimating arguments, therefore, the theory of deliberative democracy offers a legitimation of majority rule that is generated by the process of political communication and policy-oriented deliberation itself.

But even if all that is conceded on the theoretical level, there are still two fundamental objections against considering deliberative democracy as a pragmatically plausible and normatively convincing justification of majority rule at the European level. The first is empirical. The communication processes on which the theory relies for its legitimating arguments do not (yet) exist. There is presently no pan-European public space; and the national compartments of public debates are at best linked through highly selective reports in the quality press, which, even if they are increasing ${ }^{105}$, cannot substitute for the legitimating function of Europe-wide discourses. Worse yet, political debates in national public spaces are increasingly directed against each other and framed in fundamental opposition to the European Union. ${ }^{106}$ At any rate, they are hardly connected to deliberations at the European level: national political parties are not competing over European policy choices, and the European Parliament is deliberating in splendid isolation from national political debates. ${ }^{107}$ In short, European decision-making

103 Habermas, J.: Faktizität, loc. cit., 371, translation by the author.

104 The argument is reminiscent of the Condorcet Jury Theorem, which was anticipated by Rousseau (Grofman, B./Feld, S. L.: Rousseau's General Will: A Condorcetian Perspective, in: American Political Science Review, 82/2 (1988), 567-576): if truth is assumed to exist, and if all participants are independently searching for it, then the greater number of votes justifies a presumption of getting it right. But these conditions are rarely met in real-world decisions (Ladha, K. K.: The Condorcet Jury Theorem, Free Speech, and Correlated Votes, in: American Journal of Political Science, $36 / 3$ (1992), 617-634).

105 Risse, T. (ed.): European Public Spheres: Politics Is Back, Cambridge, 2015.

106 Börzel, T. A., loc. cit.

107 In my view, the most important obstacle to any attempts to "democratize" European legislation is the lack of a political linkage between the Members of the European Parliament (MEPs) and their voters. In Germany, for instance, all 93 MEPs are elected from country-wide closed lists put up by their respective national parties. Their lack of grassroots connections appears glaring when compared with the intense relationship of members of the US House of Representatives with voters, party activists, and the media in their single-member districts. And even in Germany, where the outcome of national elections is determined by proportional vote, half of the seats are filled by plurality votes in single-member districts. And as all candidates on party lists must also stand in one of these local districts, local winners will generally face local MPs elected on the list of another party as competitors for the attention of local voters. None of these local links exist for MEPs, who generally remain unknown to voters in any locality, and who are thus free to engage in European-level deliberations and power games without ever having to worry about maintaining their electoral bases. Habermas' proposal (Habermas, J.: Democracy in Europe: Why the Development of the EU into a Transnational Democracy Is Necessary and How 
processes still lack the political infrastructure and communicative linkages that would allow policy-oriented deliberation (assuming that it occurs at the European level) to be considered deliberative democracy.

The second problem of deliberative democracy in the European context is the claim that "in principle" it should be able to resolve all types of conflict through consensus-oriented arguing rather than through strategic bargaining. When what is at stake is the legitimacy of majority rule at the European level, this assumption is obviously critical - and it is also obviously unrealistic. This is not meant to deny that deliberating participants may change their prior preferences, or that randomly selected citizens in "mini publics" may achieve agreement on controversial political issues. There is also empirical research showing that actual stakeholders in local conflicts may sometimes (but by no means always) resolve these conflicts through well-designed mediation procedures. ${ }^{108}$ And there is no reason to deny that not only bargaining, but also arguing plays a role at the European level - in the Committee of Permanent Representatives and the Council Secretariat ${ }^{109}$, in some Comitology committees ${ }^{110}$, and even in committees of the European Parliament. But none of this evidence suggests that fundamental conflicts of interest, identity, or normative value orientations could also be resolved through real-world deliberative processes in national politics, let alone at the European or transnational level. ${ }^{111}$ So the conclusion must be: in constellations where consensual resolution is not within reach, majority rule cannot be legitimated by invoking the epistemological claims of deliberative democracy.

At the same time, however, the obvious unrealism of in-principle theories should not stop the search for pragmatic approximations. A parallel example on the rational-choice side is the Coase Theorem ${ }^{112}$, which postulates that in the absence of transaction costs self-interested and rational bargainers will always be able to reach agreement on the welfare optimum. But even though the assumed

It Is Possible, in: European Law Journal 21/4 (2015), 548) of European elections with pan-European lists of candidates would of course maximize the isolation of European elites.

108 Holzinger, K.: Negotiation in Public Policy-Making: Exogenous Barriers to Successful Dispute Resolution, in: Journal of Public Policy, 21/1 (2001), 81-106; Deitelhoff, N./Müller, H.: Theoretical Paradise: Empirically Lost? Arguing with Habermas, in: Review of International Studies, 31/1 (2005), 167-179.

109 Lewis, J.: How Institutional Environments Facilitate Cooperative Negotiation Styles in EU Decision Making, in: Journal of European Public Policy, 17/5 (2010), 650-666.

110 Joerges, C./Neyer, J.: From Intergovernmental Bargaining to Deliberative Political Processes: The Constitutionalization of Comitology, in: European Law Journal 3/3 (1997), 273-399.

111 McGann, A. , loc. cit.; Deitelhoff, N.: Leere Versprechungen? Deliberation und Opposition im Kontext transnationaler Legitimitätspolitik, in: Geis, A./Nullmeier, F./Daase, C. (ed.): Der Aufstieg der Legitimitätspolitik, Leviathan Special Issue 27, Baden-Baden, 2012, 63-80.

112 Coase, R. H.: The Problem of Social Cost, in: Journal of Law and Economics, 3/1 (1960), 1-44. 
condition is totally unrealistic, the theorem motivates rational-choice theorists to search for favourable constellations and useful strategies that may facilitate agreement by reducing transaction costs. ${ }^{113}$ Similarly, deliberation is likely to be more effective among groups that share an important political purpose, whereas - as Yanis Varoufakis ${ }^{114}$ had to find out - the resort to deliberative reasoning in a constellation framed as a zero-sum conflict may well contribute to further polarisation. In other words, the pragmatic usefulness of deliberation and hence the legitimating power of arguments derived from the theory of deliberative democracy will vary with the intensity of the conflicts that need to be resolved.

\section{A pragmatic approach to deliberative majority rule}

The conclusion to take from the discussion of deliberative democracy is that resort to decision by majority may not only be pragmatically useful, but also legitimate if consensus can be assumed to be within reach. The next question then is: whose consensus should be thought to matter for democratic legitimacy in institutional deliberations on European policy choices? In view of the present political conditions in the European polity, the following discussion assumes that (input-oriented) democratic legitimacy cannot be generated either by the supranational authorities of the ECB, the ECJ and the Commission, or by trans-European political parties and debates in the politically disconnected European Parliament.

Instead, I continue to assume that politically salient interests and preferences are still aggregated in national political processes and represented by politically accountable national governments in European policy processes. ${ }^{115}$ Hence, the chances of reaching deliberative consensus are primarily affected by the ex-ante constellations of interests and preferences among national governments. Regardless of the nature and origin of these preferences, such constellations can be usefully classified by the game-theoretic distinction between games of "pure conflict", games of "pure coordination", and various types of well-understood "mixed-motive games"116. In the first type of constellations, deliberation is likely

113 Scharpf, F. W.: Games, loc. cit., ch. 6.

114 Varoufakis, Y.: As It Happened: Yanis Varoufakis' Intervention during the 27th June Eurogroup Meeting, published in: Blog by Yanis Varoufakis: Thoughts for the Post-2008 World, 28.06.2015.

115 This assumption is not shared by pro-European democrats in politics and academe for whom member state governments appear as the main obstacle to European democracy. They place their hope on the Europe-wide mobilization of generalizable interests by Europe-wide political parties competing with each other on normative grounds or by appealing to class-based, rather than country-based interests. And indeed, governments cannot be idealized as self-less representatives of their national constituents; they will also defend their own institutional self-interest (Scharpf, F.W.: The Joint Decision Trap, loc. cit.).

116 Scharpf, F.W.: Games, loc. cit., ch. 4. 
to fail, and the Community Method would be blocked, whereas in intergovernmental negotiations an illegitimate settlement might be imposed through asymmetric bargaining power. In the second case of harmonious or converging preferences, in contrast, deliberation would be easy; the Community Method would work as well, and majority rule would also be unproblematic.

In actual practice, however, both of these extreme constellations are rare in European politics. Constellations resembling mixed-motive games, where all parties have an interest in cooperative solutions but will disagree about the specific terms of the settlement or the distribution of its costs and benefits, are much more common. If the decision rule is (near) unanimity, however, veto players are likely to be caught in the "negotiators' dilemma", where distributive bargaining over secondary advantages will interfere with the search for mutually acceptable cooperative solutions. ${ }^{117}$ These are the conditions under which the dominance of the consensus principle under the Community Method may either prevent political action at the European level or, after endless bargaining rounds, produce suboptimal compromises.

If deliberations or negotiations had to be carried out "in the shadow" of a majority vote, in contrast, the incentive and opportunity to "hold out" in the pursuit of minor advantages would be greatly reduced. Hence in constellations resembling the classical Battle of the Sexes or Assurance games, where for all parties possible losses on secondary (distributive) issues are outweighed by the benefits gained through achieving a common solution, the possibility of ending deliberations or negotiations through a majority vote should and probably would be preferred to non-agreement by all parties. Under these conditions, therefore, decision by majority rule would indeed be considered acceptable under the criteria of both deliberative and bargaining theory. In both cases, however, the argument depends crucially on the assumed characteristics of the interest constellations. If original preferences should diverge more widely, majority rule may turn into the "tyranny of the majority" under assumptions of rationally self-interested parties, and truth-oriented deliberation would not converge on solutions for which consensus could be assumed to be within reach. To illustrate this point, figure 1 below assumes that the multi-dimensional interests or preferences of seven actors, A, B, C, D, E, F, and G, may be represented in one dimension by the distance of their respective ideal points from the current Status Quo (SQ).

117 Lax, D. A./Sebenius, J. K.: The Manager as Negotiator: Bargaining for Cooperation and Competitive Gain, New York, 1986. 
Figure 1: Unanimity, Majority Rule, and Opt-Out

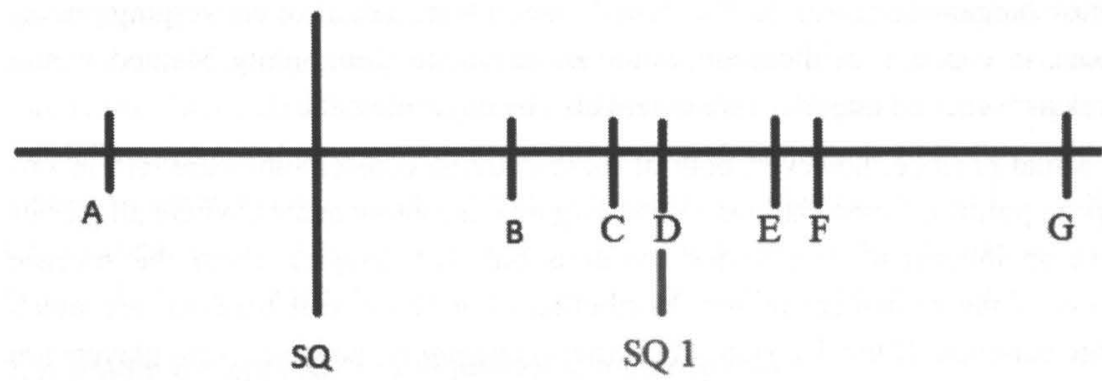

Even though all want to move away from SQ, they disagree not only about how far, but also about the direction. Under the unanimity rule, this conflict would block any agreement. If the issue should be decided by majority instead, the outcome favouring the "median voter" D would be located at SQ1. It would be better than SQ for all members of a coalition including B, C, D, E, F, and G. For government A, however, SQ1 appears so much worse than SQ that it would surely oppose it. If the country were nevertheless bound by the vote, it would have reason to consider the decision an illegitimate exercise of tyrannical majority power.

Under the assumed conditions, illegitimacy could only be avoided in two ways. A's interests could be protected by a return to the unanimity rule - which would, however, block the policy changes desired by all other parties. On the other hand, A could be exempted from the decision - which would protect its preference for SQ over SQ1, but would not prevent the other parties from adopting a policy that they jointly prefer over SQ.

When applied to the problems of European politics, the model has two implications: it demonstrates that the legitimacy of moving from the consensual rules of the Community Method to decisions by majority rule (under the no-demos conditions of the European Union) depends crucially on the existence of interest constellations in which it is indeed plausible to think that consensus is within reach, and that for all parties concerned the benefits of a roughly acceptable common outcome exceed the costs of an individually suboptimal solution. At a time, however, when the extremely diverse and unequal "peoples of Europe" are driven apart under the impact of multiple crises ${ }^{118}$, such conditions cannot be generally

118 Armingeon, K./Guthmann, K. /Weisstanner, D.: How the Euro Divides the Union: The Effect of Economic Adjustment on Support for Democracy in Europe, in: Socio-Economic Review, 14/1 (2016), 1-26. 
assumed. But where they do not exist, decisions by majority vote that violate highly salient interests or values of the minority would lack legitimacy and might provoke disruptive conflict in a Union that still depends on the consensus principle.

Unfortunately, there is no substantive ex-ante test that could generally and reliably identify constellations where the application of the majority rule would be normatively appropriate or clearly unacceptable. But there may be a procedural equivalent: the use of the majority rule could be combined with the possibility of an opt-out that would restrict the legal effect of the decision to member states whose governments participate in the vote - and who presumably expect to gain from a European solution even if they should be outvoted on some of its details. In effect, this procedure would simultaneously protect highly salient minority interests, reduce the probability of political blockades, and allow "coalitions of the willing" to use the powers of European legislation to deal with common problems and advance common purposes that are beyond the reach of individual member states acting on their own.

In practical terms, this would imply having two different "ordinary legislative procedures". The first one would basically consist of the "Community Method" defined in the present Article 294 TFEU, but modified to accommodate the possibility of legislative initiatives introduced by governments in the Council and factions in the European Parliament. The second procedure would allow legislation to be adopted by plurality votes in Council and Parliament, and it would have to regulate the conditions, procedures, and effects of national opt-outs. In principle, these rules should allow for political choices dealing with two problems.

First, there may be legislation for which Europe-wide and uniform application is considered essential - perhaps for normative or symbolic reasons or because the problem to be regulated is thought to have "leaky-bucket" characteristics where the effect of the common rule would be undermined by the free-riding of opt-out states. Hence, the promoters of an initiative should be free to choose initially between one or the other of two "ordinary procedures," and they may also be allowed to withdraw an initiative in the majoritarian procedure after optouts have been declared. In any case, however, member states that have initially chosen the opt-out should be allowed to accede subsequently to the regime created by majority vote.

Second, majoritarian legislation might be designed to damage the interests of opt-out states. In that case, sufficient protection may be provided by present Treaty rules against discrimination on account of nationality. Beyond that, one 
might also consider rules imposing an upper limit on allowable opt-outs (defined by reference to population or to the number of member states) in order to avoid extreme forms of legal differentiation in the European Union. Smaller groups of states pursuing common purposes would then be left to try the much more circumscribed and essentially non-political procedures allowing for "enhanced cooperation" (Articles 326-334 TFEU). Whether such a rule is required and where such a limit should be drawn are matters of judgment that, like the majority-cum-opt-out proposal itself, resonate with fundamental and controversial views on the purposes of European integration and the value of legal uniformity, which I will now turn to in the concluding section.

\section{Differentiated integration and the empowerment of democratic politics}

European integration has been promoted to serve two different purposes that were not clearly distinguished because they were thought to reinforce each other; and it was also associated with one great hope. The first purpose, driven by strong anti-nationalist motives after the Second World War, ${ }^{119}$ was the establishment of a United States of Europe as a supranational, externally powerful, and politically integrated federal state. The other, more pragmatic purpose is best expressed by the title of Alan Milward's bestseller, "The European Rescue of the Nation State" 120 : member states agreed to a partial transfer of sovereignty, and to its joint exercise, in order to obtain European solutions to problems that could no longer be successfully resolved at the national level. And the great hope was that both purposes could be realised with democratic legitimacy. In the meantime, however, the purposes are perceived to be in partial conflict, and the hopes for democratic self-government in Europe have been disappointed.

To date, the greatest achievements of the "federalist" impetus have been the common market, the common currency, and a European legal order whose constitutional authority is as comprehensive and effective as that of any constitutional state, federal or unitary. From the perspective of EU member states, however, the Monetary Union has not only failed to resolve any of their existing problems, but is also the main cause of massive problems for many of them,

119 By viewing the Second World War as a catastrophe of excess nationalism, this interpretation fails to realize that Nazi Germany's vision for post-war Europe was not the reinforcement of a German nationstate, but the establishment of a transnational European empire under German direction (Hank, R: Wir Europäer: Nach der verlorenen Unschuld, in: Merkur 67/773 (2013), 872-885).

120 Milward, A. S.: The European Rescue of the Nation-State, Oxford, 1992. 
while European law, by constitutionalising "negative integration," is imposing ever tighter constraints on the action space of EU member states.

At the same time, however, the second purpose is reflected in an institutional structure in which member states remain in control not only of the transfer of governing powers, but also of their exercise at the European level. Given their increasing number and diversity, this institutional framework has come to defeat its original purpose. It implies that the political capacity of the European polity, whose legal system is that of a federal state, is nearly as limited as that of a cooperative federation.

As a consequence of these conflicts and disappointments, the present debate about European integration has become increasingly polarised. Proponents of the "federalist" goal, among them institutional actors at the European level but also many pro-European democrats in civil society, are implicitly hostile to the European nation-state. They attribute most of what is thought to be wrong in the European Union to the recalcitrance, egotism, and myopia of member state governments defending national (and institutional) self-interest at the expense of the European common good. The proper remedy, as they see it, would be a wholesale transfer of constitutional sovereignty, competences, and governing resources to a democratic European state. In the meantime, in any case, the aquis must be defended, and existing controls over national governments and policies must be reinforced and extended.

At the other extreme, right- and left-wing "populist" movements, political parties, and governments are blaming the rise of social inequality, economic failure, and the frustrations of collective identities by global capitalism and migration on neoliberal and power-hungry European technocrats. But there are also politically responsible and responsive governments and democratic political parties that are frustrated by the lack of problem-solving effectiveness and the absence of democratic accountability in European governance. They may not be ready to imitate the Brexit-campaign, but appear to be increasingly willing to explore the options of "devolution", re-nationalisation, or a resort to intergovernmental action. The present paper is not committed to either a federalist or a national perspective: it is meant to explore options that may strengthen European and national capacities for effective and democratically legitimate political action in the face of critical external and internal challenges.

Admittedly, by limiting the constitutional effect of economic liberties and by allowing opt-outs from European legislation these proposals would reduce the 
coverage and increase the territorial fragmentation of European law. At the same time, however, they would not only re-empower democratic debates over the shape of national political economies, but they would also improve the prospects of European political integration and democratic legitimacy: The possibility of majoritarian European legislation would widen the range of potentially feasible European policy choices, which might lessen the deadening sense of futility that presently inhibits the search for European options. It would then be more plausible for national governments, political parties, labor unions, and NGOs to try to mobilise political support and media attention for and against European policy initiatives that would be nipped in the bud under present rules. Moreover, opting out would also be a politically salient decision that governnments would have to justify to their European peers as well as to their national publics. In the end, therefore, the politicisation of controversies over European policy choices, and the importance of having to build transnational coalitions for their realisation, might not only revitalise democratic politics, but also contribute to the evolution of a European public space and to the political integration of the "peoples of Europe". 